\title{
Telmisartan Improves Cardiometabolic Profile in Obese Patients with Arterial Hypertension
}

\author{
Małgorzata Kubik $^{\mathrm{a}}$ Jerzy Chudek ${ }^{\mathrm{a}, \mathrm{b}}$ Marcin Adamczak ${ }^{\mathrm{a}}$ Andrzej Wiecek

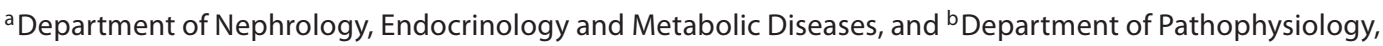 \\ Medical University of Silesia, Katowice, Poland
}

\section{Key Words}

Insulin resistance $\cdot$ Adiponectin $\cdot$ Leptin $\cdot$ Interleukin-8

\begin{abstract}
Objective: There are several lines of evidence that telmisar$\tan$ may improve cardiometabolic profile. The aim of the study was to estimate changes of insulin resistance and plasma concentrations of adipokines after long-term antihypertensive treatment with telmisartan in obese hypertensive patients. Methods: 34 previously untreated obese adults with arterial hypertension were enrolled. Glucose cellular uptake ( $M$ value) and the $M$ to insulin ratio $(M / I$ value) were measured by euglycemic-hyperinsulinemic clamp technique, body fat content (by dual-energy X-ray absorptiometry method), as well as plasma concentrations of selected adipokines and cytokines were estimated before and after 6-month telmisartan therapy in 25 patients who completed the study. Results: Telmisartan therapy was followed by $14.2 \%$ decrease of systolic and by $19.6 \%$ decrease of diastolic blood pressure. Body fat mass did not change significantly. Both $M$ and $M / I$ values (by 24.4 and by $38.6 \%$, respectively) as well as plasma levels of total and high-molecular-weight adiponectin (by 10.8 and by $23.5 \%$, respectively) increased significantly. Plasma concentrations of high-sensitivity C-
\end{abstract}

\section{KARGER}

Fax +4161306 1234

E-Mail karger@karger.ch

www.karger.com (c) 2012 S. Karger AG, Basel

$1420-4096 / 12 / 0354-0281 \$ 38.00 / 0$

Accessible online at:

www.karger.com/kbr reactive protein and interleukin-8 decreased significantly, while those of interleukin- 6 and tumor necrosis factor- $\alpha$ tended to decline. Conclusions: Telmisartan monotherapy improves cardiometabolic profile in obese hypertensive patients by improving insulin sensitivity and increasing of plasma adiponectin concentration, including its high-molecularweight fraction, and by suppressing of microinflammation.

Copyright $\odot 2011$ S. Karger AG, Basel

\section{Introduction}

In view of the current pandemic of obesity and diabetes mellitus type 2 in both developed and developing countries [1,2], the usage of antihypertensive drugs with beneficial metabolic properties in the treatment of arterial hypertension becomes of great clinical challenge. $\beta$ Blockers and diuretics were proved to have a detrimental influence on insulin sensitivity and glucose metabolism, calcium channel blockers seem to be metabolically neutral, while angiotensin-converting enzyme inhibitors and angiotensin receptors blockers (ARBs) may improve metabolic profile [3].

The results from studies estimating the influence of $\mathrm{ARBs}$ on insulin sensitivity are not consistent. In the 
LIFE study a significant reduction of new-onset diabetes mellitus was found after losartan therapy in comparison with patients receiving atenolol [4]. However, the favorable effect of losartan could result only from $\beta$-blockers' diabetogenic properties. Additionally, a significantly lower rate of diabetes was found in patients treated with valsartan in comparison to amlodipine in the VALUE study [5]. However, in the SCOPE study such differences between candesartan and placebo did not reach the statistical significance [6].

Telmisartan - one of the ARBs - has some structural similarities to antidiabetic agent pioglitazone (a peroxisome proliferator activated receptor- $\gamma$ (PPAR $\gamma$ ) agonist) [7]. Activation of PPAR $\gamma$ regulates carbohydrate and lipid metabolism and influences the inflammatory processes [8]. Therefore, it was hypothesized that telmisartan might have a beneficial influence on insulin sensitivity.

Insulin resistance is often associated with the excess of white adipose tissue which is not only an energy storage, but also an important source of biologically active substances named adipokines. Adipokines have endocrine and paracrine properties and may influence whole body metabolism. One of them is adiponectin that is supposed to have anti-diabetic, anti-inflammatory and anti-atherogenic properties. Plasma adiponectin concentration is reduced in patients with obesity [9], diabetes mellitus type 2 [10], hypertension [11] and coronary heart disease [12]. In the circulation, adiponectin molecules form several types of multimers: trimers, hexamers to 12-mers and 18-mers (high molecular weight, HMW) [13]. There are several lines of evidence suggesting that the anti-diabetic and anti-atherogenic properties of this hormone are related mainly to HMW fraction of adiponectin [14-16]. In contrast to adiponectin, serum concentration of leptin increases along with the mass of adipose tissue [17]. In obese subjects, elevated leptin concentration is involved in the pathogenesis of arterial hypertension and obesityrelated glomerulopathy [18]. It was shown that stimulation of PPAR $\gamma$ receptors by thiazolidinediones increases plasma adiponectin concentration (and especially its HMW fraction) [19] and diminishes plasma leptin concentration [20].

Adipose tissue is also an important source of proinflammatory cytokines including tumor necrosis factor- $\alpha$ $(\mathrm{TNF} \alpha)$, interleukin (IL)-6 and IL-8. It is believed that these proinflammatory cytokines participate in the pathogenesis of atherosclerosis and insulin resistance. It was shown that TNF $\alpha$ increases insulin resistance directly (by altering of insulin signaling) and indirectly by reducing adiponectin secretion [21] and increasing the oxi- dative stress [22]. The secretion of IL- 6 is increased in obese and insulin-resistant subjects [23, 24]. It was shown that IL- 6 exerts detrimental effects on carbohydrates and lipid metabolism $[25,26]$, and reduces adiponectin secretion [27]. IL-8 plays a role in the pathogenesis of atherosclerosis and insulin resistance $[28,29]$. Its concentration is also increased in obese subjects [30].

The euglycemic-hyperinsulinemic clamp originally described by DeFronzo et al. [31] in 1979 remains a 'gold standard' for insulin sensitivity estimation. Until now the euglycemic-hyperinsulinemic clamp technique as a modified version has been applied only in a single published study estimating the influence of telmisartan on insulin resistance [32]. However, the duration of telmisartan treatment was shorter ( 8 weeks) than in our study (6 months).

There are also only few studies examining the influence of telmisartan on circulating adipokines and proinflammatory cytokine concentration. Therefore, the aim of the study was to estimate changes of insulin resistance by the euglycemic-hyperinsulinemic clamp technique, plasma levels of total adiponectin and its HMW fraction, and several proinflammatory cytokines after long-term antihypertensive treatment with telmisartan in obese patients with arterial hypertension.

\section{Methods}

\section{Study Protocol}

Thirty-four obese (BMI between 30 and $40 \mathrm{~kg} / \mathrm{m}^{2}$ ) adult patients with mild or moderate hypertension without diabetes mellitus were enrolled in this study. These patients were recruited from previously untreated hypertensive patients referred to the outpatient clinic. None of the patients were taking any antihypertensive drugs or drugs affecting insulin sensitivity for at least 4 weeks before entering the study. The study protocol was approved by local ethics committee and informed consent was obtained from each patient. Patients received telmisartan (Micardis; Boehringer Ingelheim) in monotherapy at the initial dose of $40 \mathrm{mg}$ once per day. Blood pressure was estimated at the beginning, at the end of the study and every month during control visits. Blood pressure was measured on the left arm according to the Korotkoff method using a standard mercury sphygmomanometer with a cuff of appropriate size. Measurements were always taken three times by the same, single investigator in the morning after resting for $5 \mathrm{~min}$ in the seating position. The mean from the measured values was then calculated. A daily dose of telmisartan ( 40 or $80 \mathrm{mg} /$ day) was adjusted to achieve blood pressure values $<130 / 85 \mathrm{~mm}$ Hg. Patients who did not obtain such a blood pressure after 1-month treatment with the maximum dose of telmisartan were excluded from the study. 25 patients completed the study (table 1). The mean dose of telmisartan after 6 months was $56 \pm 20 \mathrm{mg}$ /day. 
Table 1. Characteristics of patients with arterial hypertension and obesity who completed the study (data are given as mean $\pm \mathrm{SE}$ or median with interquartile range and range of values)

\begin{tabular}{|c|c|c|}
\hline Male/female & $11 / 14$ & \\
\hline Age, years & $50.7 \pm 8.9$ & $34.0-65.0$ \\
\hline Body mass, $\mathrm{kg}$ & $101.5 \pm 14.4$ & $77.0-130.4$ \\
\hline BMI & $35.2 \pm 3.8$ & $30.1-39.4$ \\
\hline Waist circumference, $\mathrm{cm}$ & $111.7 \pm 7.9$ & $97.5-125.0$ \\
\hline Systolic blood pressure, $\mathrm{mm} \mathrm{Hg}$ & $148.0 \pm 8.0$ & $135.0-60.0$ \\
\hline Diastolic blood pressure, $\mathrm{mm} \mathrm{Hg}$ & $97.0 \pm 8.0$ & $80.0-110.0$ \\
\hline Hemoglobin, g/dl & $14.2 \pm 1.3$ & $11.5-17.0$ \\
\hline Leukocytes, $10^{3} / \mu \mathrm{l}$ & $7.2 \pm 1.8$ & $3.7-10.9$ \\
\hline Neutrophils, $10^{3} / \mu \mathrm{l}$ & $4.0 \pm 1.3$ & $1.6-6.9$ \\
\hline Platelets, $10^{3} / \mu \mathrm{l}$ & $228.0 \pm 50.0$ & $135.0-311.0$ \\
\hline hsCRP, mg/l & $4.2(3.1-5.2)$ & $3.0-14.7$ \\
\hline Total cholesterol, mmol/l & $5.5 \pm 1.1$ & $3.5-7.4$ \\
\hline LDL cholesterol, mmol/l & $3.3 \pm 0.9$ & $1.7-5.4$ \\
\hline HDL cholesterol, mmol/l & $1.2 \pm 0.3$ & $0.7-1.9$ \\
\hline Triglycerides, mmol/l & $1.8 \pm 1.5$ & $0.6-7.4$ \\
\hline Sodium, mmol/l & $141.8 \pm 2.8$ & $136.0-147.0$ \\
\hline Potassium, mmol/l & $4.1 \pm 0.3$ & $3.7-4.8$ \\
\hline Creatinine, $\mu \mathrm{mol} / \mathrm{l}$ & $83.1 \pm 14.3$ & $52.4-112.0$ \\
\hline $\mathrm{eGFR}, \mathrm{ml} / \mathrm{min} / 1.73 \mathrm{~m}^{2}$ & $79.6 \pm 19.5$ & $49.5-151.3$ \\
\hline Glucose, $\mathrm{mmol} / \mathrm{l}$ & $4.9 \pm 0.4$ & $4.4-5.7$ \\
\hline Total adiponectin, $\mu \mathrm{g} / \mathrm{ml}$ & $7.6 \pm 4.4$ & $2.0-20.8$ \\
\hline Fraction HMW of adiponectin, $\mu \mathrm{g} / \mathrm{ml}$ & $1.7 \pm 1.0$ & $0.4-4.1$ \\
\hline Fraction non-HMW of adiponectin, $\mu \mathrm{g} / \mathrm{ml}$ & $5.9 \pm 3.7$ & $1.3-17.3$ \\
\hline Leptin, ng/ml & $25.2 \pm 16.5$ & $4.7-72.7$ \\
\hline $\mathrm{TNF} \alpha, \mathrm{pg} / \mathrm{ml}$ & $4.4 \pm 2.0$ & $1.8-8.6$ \\
\hline IL-6, pg/ml & $3.5 \pm 2.4$ & $1.0-10.0$ \\
\hline $\mathrm{IL}-8, \mathrm{ng} / \mathrm{ml}$ & $3.8 \pm 2.1$ & $0.7-9.1$ \\
\hline Insulin, $\mu \mathrm{U} / \mathrm{ml}$ & $20.6 \pm 12.2$ & $4.7-49.7$ \\
\hline $\mathrm{M}, \mathrm{mg} / \mathrm{kg} / \mathrm{min}$ & $4.1 \pm 2.0$ & $1.0-7.2$ \\
\hline $\mathrm{M} / \mathrm{I}, \mathrm{mg} / \mathrm{kg} / \mathrm{min} / \mu \mathrm{U} / \mathrm{ml}$ & $4.4 \pm 3.3$ & $0.6-12.0$ \\
\hline HOMA-IR & $4.6 \pm 2.8$ & $1.1-9.9$ \\
\hline QUICKI & $0.23 \pm 0.03$ & $0.18-0.31$ \\
\hline
\end{tabular}

M value = Glucose cellular uptake; $\mathrm{I}=$ insulin plasma concentration; $\mathrm{M} / \mathrm{I}$ ratio $=$ a marker of tissues sensitivity to insulin; HMW = high-molecular-weight fraction of adiponectin.

Body weight and waist circumference were measured at every visit. Before and after 6 months of treatment with telmisartan the following parameters were estimated: insulin sensitivity by an euglycemic-hyperinsulinemic clamp technique (and additionally homeostasis model assessment of insulin resistance (HOMA-IR) and QUICKI indexes were calculated before initiation of telmisartan treatment based on the fasting insulin and glucose concentrations $[33,34])$, serum concentration of high-sensitivity Creactive protein (hsCRP), creatinine, sodium, potassium, plasma concentration of total adiponectin and its HMW fraction, leptin, IL-6, IL- 8 and TNF $\alpha$, and body fat content by dual energy X-ray absorptiometry (DEXA) using a Lunar DPX-L scanner (Lunar Radiation Co., Madison, Wisc., USA). Additionally, blood count and lipid profiles were tested every month. Serum creatinine and plasma sodium and potassium concentrations as well as the activity of aminotransferases were also measured 2 weeks after initiation of treatment with telmisartan due to safety reasons.

\section{Euglycemic-Hyperinsulinemic Glucose Clamp}

A euglycemic-hyperinsulinemic glucose clamp technique is regarded as a 'gold standard' for insulin sensitivity estimation. It was performed according to the method described by DeFronzo et al. [31]. Two veins on both forearms were cannulized. To the right cannula insulin dissolved in $20 \%$ glucose solution were infused. During the first $8 \mathrm{~min}$ the rate of insulin infusion was gradually decreased from 100 to $60 \mathrm{mU} / \mathrm{m}^{2} / \mathrm{min}$. Afterwards, insulin was infused at a stable speed of $50 \mathrm{mU} / \mathrm{m}^{2} / \mathrm{min}$ throughout the clamp study, which achieves a mean plasma insulin concentration of about 100-120 mU/l (physiologic insulin concentration after an average meal). Glucose infusion rate was adjusted to the current blood glucose level to maintain the patients in a stable euglycemic state. Glucose concentration was estimated every 5 min during the first $2 \mathrm{~h}$ and every $10 \mathrm{~min}$ during the third hour from the left cannula. Glucose blood concentration was estimated with the use of glucometer Medisense Optium (precision of glucose 
Table 2. Selected parameters in obese, hypertensive patients before and after 6 months of telmisartan treatment (mean \pm SD values are shown)

\begin{tabular}{|c|c|c|c|c|}
\hline & Before & After & $\mathrm{p}$ & Difference, $\%$ \\
\hline Body mass, $\mathrm{kg}$ & $101.5 \pm 14.4$ & $102.7 \pm 15.4$ & 0.05 & +1.2 \\
\hline Waist circumference, $\mathrm{cm}$ & $111.7 \pm 7.9$ & $110.6 \pm 8.7$ & 0.29 & -1.0 \\
\hline Total fat content, kg & $39.3 \pm 8.0$ & $40.8 \pm 9.3$ & 0.07 & +3.8 \\
\hline Systolic blood pressure, $\mathrm{mm} \mathrm{Hg}$ & $148.0 \pm 8.0$ & $127.0 \pm 6.0$ & $<0.001$ & -14.2 \\
\hline Diastolic blood pressure, $\mathrm{mm} \mathrm{Hg}$ & $97.0 \pm 8.0$ & $78.0 \pm 6.0$ & $<0.001$ & -19.6 \\
\hline $\mathrm{M}, \mathrm{mg} / \mathrm{kg} / \mathrm{min}$ & $4.1 \pm 2.0$ & $5.1 \pm 3.0$ & 0.02 & +24.4 \\
\hline $\mathrm{M} / \mathrm{I}, \mathrm{mg} / \mathrm{kg} / \mathrm{min} / \mu \mathrm{U} / \mathrm{ml}$ & $4.4 \pm 3.3$ & $6.1 \pm 4.5$ & 0.02 & +38.6 \\
\hline Glucose, $\mathrm{mmol} / \mathrm{l}$ & $4.9 \pm 0.4$ & $5.1 \pm 0.5$ & 0.25 & +4.1 \\
\hline Insulin, $\mu \mathrm{U} / \mathrm{ml}$ & $20.6 \pm 12.2$ & $21.3 \pm 13.0$ & 0.658 & +3.4 \\
\hline Total adiponectin, $\mu \mathrm{g} / \mathrm{ml}$ & $7.6 \pm 4.4$ & $8.4 \pm 4.1$ & 0.02 & +10.8 \\
\hline HMW fraction of adiponectin, $\mu \mathrm{g} / \mathrm{ml}$ & $1.7 \pm 1.0$ & $2.1 \pm 1.4$ & 0.03 & +23.5 \\
\hline Leptin, $\mathrm{ng} / \mathrm{ml}$ & $25.2 \pm 16.5$ & $24.6 \pm 15.3$ & 0.25 & -2.4 \\
\hline hsCRP, mg/l & $5.1 \pm 2.9$ & $4.1 \pm 1.9$ & 0.02 & -19.6 \\
\hline IL-8, ng/ml & $3.8 \pm 2.1$ & $2.7 \pm 1.9$ & 0.03 & -28.9 \\
\hline $\mathrm{TNF} \alpha, \mathrm{pg} / \mathrm{ml}$ & $4.4 \pm 2.0$ & $4.1 \pm 1.0$ & 0.91 & -9.1 \\
\hline IL-6, pg/ml & $3.5 \pm 2.4$ & $3.4 \pm 2.3$ & 0.62 & -2.9 \\
\hline HDL cholesterol, $\mathrm{mmol} / \mathrm{l}$ & $1.2 \pm 0.3$ & $1.4 \pm 0.3$ & $<0.001$ & +16.7 \\
\hline LDL cholesterol, mmol/l & $3.3 \pm 0.9$ & $3.4 \pm 1.0$ & 0.88 & +3.0 \\
\hline Triglycerides, mmol/l & $1.8 \pm 1.5$ & $1.6 \pm 1.1$ & 0.77 & -11.1 \\
\hline Potassium, mmol/l & $4.1 \pm 0.3$ & $4.4 \pm 0.3$ & 0.003 & +7.3 \\
\hline
\end{tabular}

M value = Glucose cellular uptake; $\mathrm{I}=$ insulin plasma concentration; $\mathrm{M} / \mathrm{I}$ ratio $=$ a marker of tissues sensitivity to insulin; HMW = high-molecular-weight fraction of adiponectin.

estimation for high and low values was 2.9-5.1\%). Plasma insulin concentration was estimated at the beginning of the clamp study and then every $60 \mathrm{~min}$. The glucose cellular uptake (M value; milligrams per kilogram per minute) was calculated as a mean of three glucose infusion rates achieved in last three 20 -min periods of the clamp study. Glucose cellular uptake to plasma insulin concentration ratio $(\mathrm{M} / \mathrm{I}$ value, $\mathrm{mg} / \mathrm{kg} / \mathrm{min} / \mu \mathrm{U} / \mathrm{ml})$ was considered as a marker of tissue sensitivity to insulin.

\section{Laboratory Investigations}

Plasma insulin was measured using enzyme-linked immunosorbent assay (ELISA) kits for Elecsys from Roche Diagnostics $\mathrm{GmbH}$ (Mannheim, Germany). Plasma total adiponectin concentration and its HMW fraction concentration was measured using ELISA kits from Linco Research Laboratories (St. Louis, Mo., USA). A radioimmunoassay method was applied for estimation of plasma leptin (Linco Research Laboratories) and TNF $\alpha$ (BioSource Europe SA, Nivelles, Belgium). Plasma IL-6 and IL-8 concentrations were measured using high-sensitivity ELISA kits from R\&D Systems (Minneapolis, Minn., USA). Serum CRP concentration was measured by nephelometric method using 'CardioPhase hsCRP' kits from Siemens Healthcare Diagnostics (Deerfield, Ill., USA).

Serum cholesterol (total and HDL fraction), triglyceride, and creatinine concentrations were measured by an automated method (Synchron Cx-9; Beckman Coulter Inc., Fullerton, Calif., USA).

\section{Statistics}

Statistical analysis was performed using Statistica version 7.0. All quantitative variables are expressed as mean \pm SD or in median with interquartile range. Wilcoxon test was used to determine the differences between dependent variables. $\mathrm{p}<0.05$ was considered as statistically significant.

\section{Results}

All study participants had abdominal obesity (according to IDF definition from 2005), and 22 of 25 patients fulfilled the population criteria of insulin resistance (HOMA-IR $\geq 2.29$ for the European population [35]). The average value of HOMA-IR was 4.6. Detailed characteristics of the study group before and after treatment of telmisartan are given in tables 1 and 2 .

The 6-month therapy with telmisartan was followed by a significant decrease of systolic (by $14.2 \%, \mathrm{p}<0.001$ ) and diastolic (by 19.6\%, p < 0.001) blood pressure (table 2). Transient hypotension was observed in 2 patients. No changes in total body mass, BMI, waist circumference and total fat content estimated by DEXA were observed. 

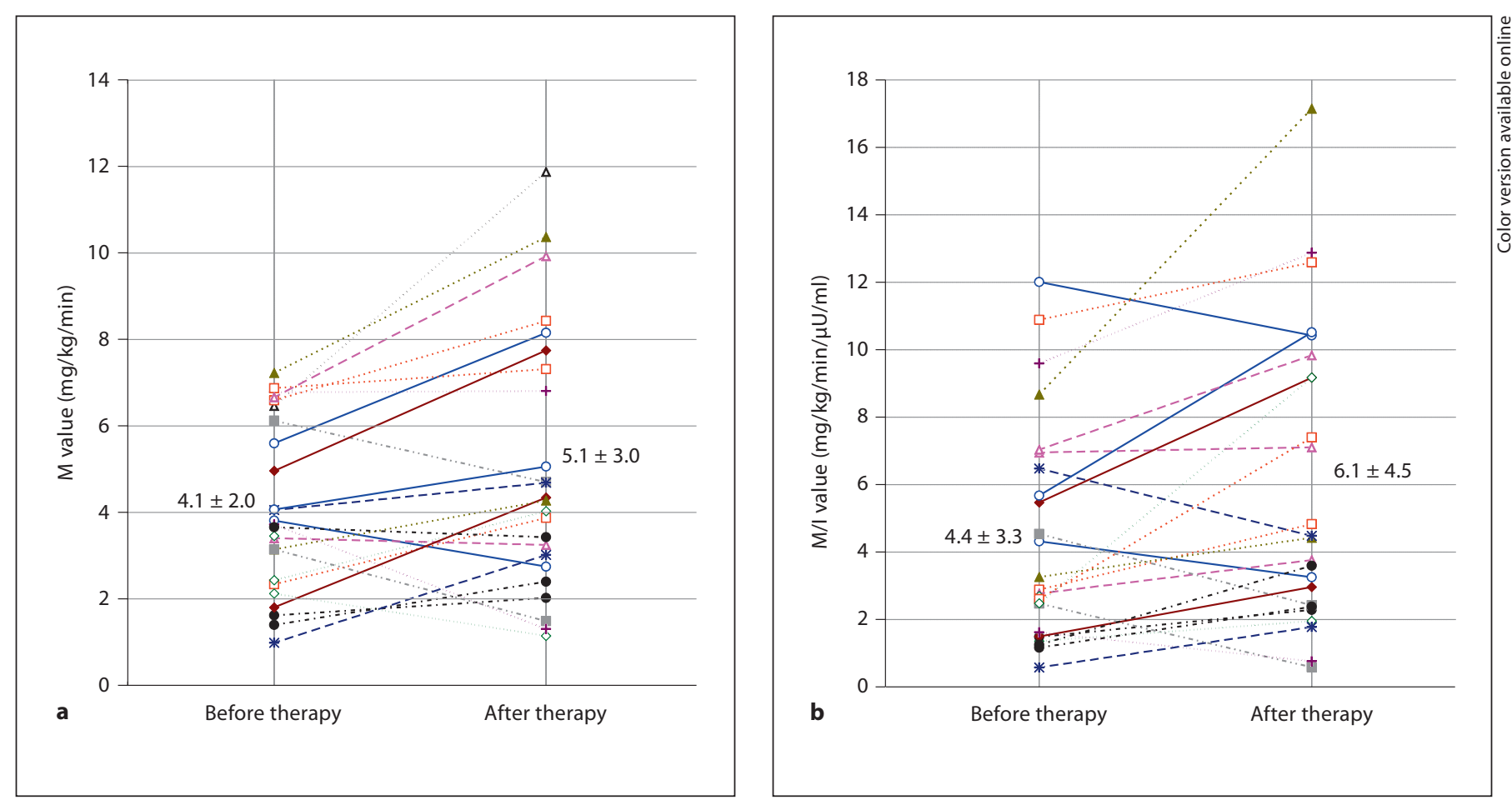

Fig. 1. a $M$ values in 25 patients before and after 6 months of telmisartan treatment $(p=0.02)$. b M/I values in 25 patients before and after 6 months of telmisartan treatment $(p=0.02)$.

The only significant change in lipid profile after the 6 -month telmisartan treatment was the increase in the concentration of HDL cholesterol $(\mathrm{p}<0.001)$ (table 2).

After the 6-month telmisartan therapy an increase of insulin sensitivity parameters was demonstrated: the $\mathrm{M}$ value by $24.4 \%(\mathrm{p}=0.02)$ (table 2 ; fig. 1a) and the $\mathrm{M} / \mathrm{I}$ value by $38.6 \%(\mathrm{p}=0.02)$ (table 2 ; fig. $1 \mathrm{~b}$ ). There was no change in fasting glucose and insulin concentration.

A significant increase in plasma adiponectin concentration (by $10.8 \%, \mathrm{p}=0.02$ ) (table 2; fig. $2 \mathrm{a}$ ) and its HMW fraction (by $23.5 \%, \mathrm{p}=0.03$ ) (table 2 ; fig. $2 \mathrm{~b}$ ) was observed. There was no significant change in plasma leptin concentration (table 2).

Moreover, after the 6-month telmisartan therapy a significant reduction of inflammatory parameters was observed: hsCRP by $19.2 \%(\mathrm{p}=0.02)$ and IL- 8 by $28.9 \%$ $(\mathrm{p}=0.03)$ (table 2). The concentrations of IL- 6 and TNF $\alpha$ also tended to decrease, but the observed changes did not reach statistical significance (table 2).

\section{Side Effects}

No side effects were observed during the 6-month therapy with telmisartan. The average serum potassium concentration rose significantly (by $0.3 \mathrm{mmol} / \mathrm{l}, \mathrm{p}=$ 0.003) (table 2), but in all patients serum potassium concentrations remained within the normal range.

\section{Discussion}

The study revealed that 6-month treatment with telmisartan improves insulin sensitivity, increases the concentration of serum adiponectin and its HMW fraction and decreases concentrations of the inflammatory markers in obese patients with arterial hypertension.

The main goal of the present study was the estimation of changes of insulin resistance after 6 months of antihypertensive treatment with telmisartan, based on the euglycemic-hyperinsulinemic glucose clamp technique, which is a 'gold standard' for insulin sensitivity studies. We have found a significant increase of the $\mathrm{M}$ parameter without a concomitant reduction of glucose and insulin serum concentration. Our group failed to demonstrate such an increase in the $\mathrm{M}$ parameter in a group of hypertensive patients after 8 weeks of therapy with losartan [36]. Perhaps the beneficial influence of telmisartan on 

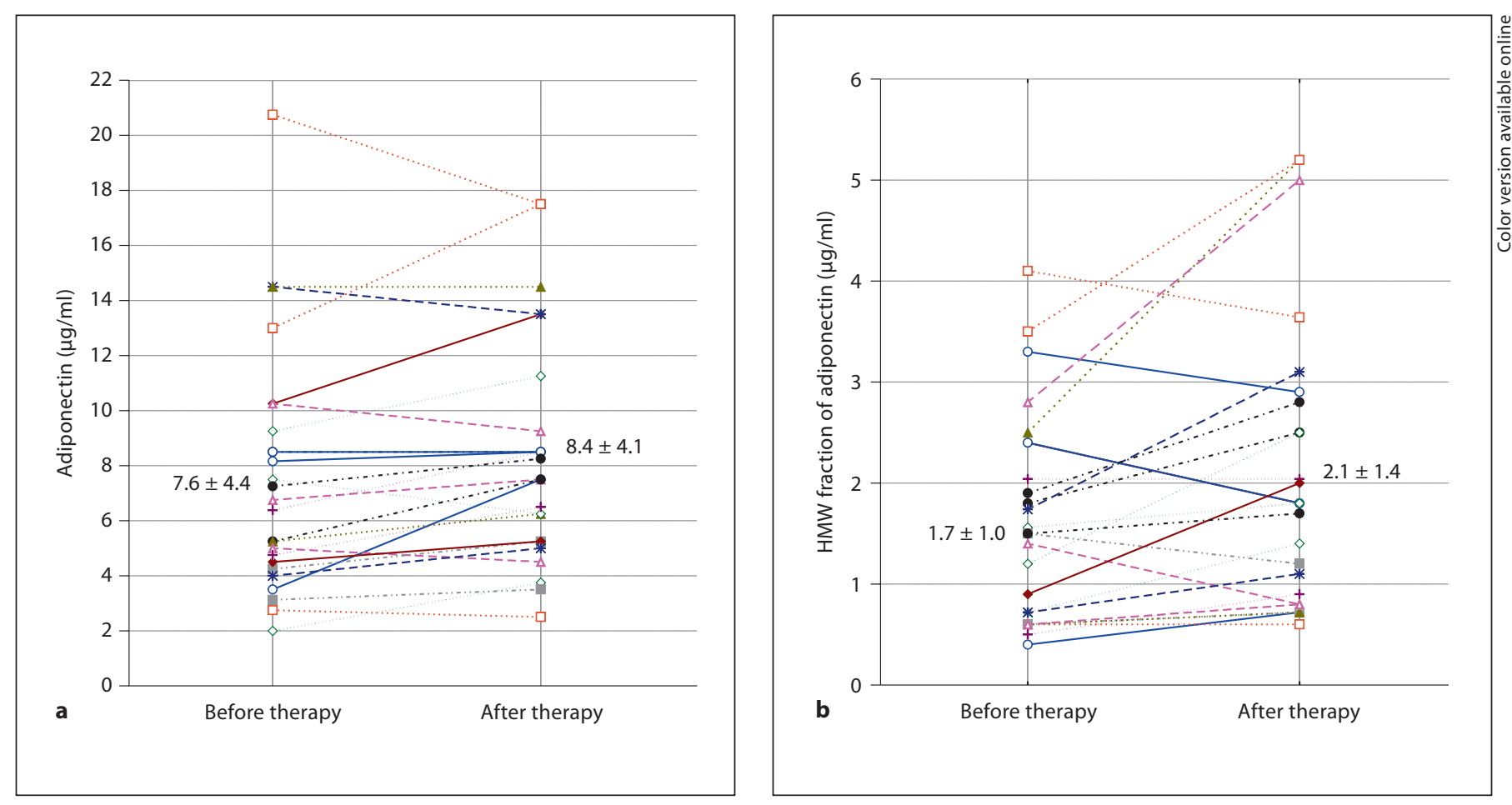

Fig. 2. a Plasma adiponectin concentrations in 25 patients before and after 6 months of telmisartan treatment $(\mathrm{p}=0.02)$. b Plasma HMW fraction of adiponectin concentrations in 25 patients before and after 6 months of telmisartan treatment $(\mathrm{p}=0.03)$.

insulin sensitivity might be partially explained by the activation of PPAR $\gamma$ receptor. However, the beneficial effect of PPAR $\gamma$ stimulation by sartans has not been incontestably proven. Sharma et al. [37] did not observe any difference in fasting glucose concentration in head-to-head comparison between telmisartan with valsartan (that lacks PPAR $\gamma$ activity).

The improvement of insulin sensitivity during telmisartan treatment has also been observed in other studies in hypertensive patients with obesity and/or diabetes/impaired glucose tolerance, however based on other than glucose clamp methods [38-41]. Only in a few of those studies was a significant reduction of serum insulin and glucose concentration found. Vitale et al. [42] investigated 40 patients randomly allocated to two groups receiving telmisartan or losartan. After 3 months, patients in the telmisartan group were characterized by a significant reduction of glycemia, insulinemia, HbAlc and HOMAIR index. In the other study no beneficial effect of telmisartan treatment on insulin sensitivity was observed in 42 patients with metabolic syndrome treated alternatively with telmisartan or losartan [43]. A similar result was obtained by Derosa et al. [44] in a group of 119 diabetic patients treated with telmisartan, eprosartan or placebo. The results of the above-mentioned studies should not be directly compared with the current study because insulin sensitivity indexes such as HOMA-IR and QUICKI calculated from fasting insulinemia and glycemia reflect mainly hepatic insulin sensitivity. In the current study the $\mathrm{M}$ parameter measured with the euglycemic-hyperinsulinemic glucose clamp technique reflects the peripheral tissue glucose uptake. The M/I ratio is considered as a marker of insulin resistance. The euglycemic-hyperinsulinemic clamp originally described by DeFronzo et al. [31] in 1979 still remains a 'gold standard' for estimating insulin sensitivity. Until now the euglycemic-hyperinsulinemic clamp technique for the estimation of the influence of telmisartan on insulin resistance has been applied only in a single, recently published study [32]. The results of that study are in line with the ones achieved in the current study.

What is the clinical meaning of the improvement of insulin sensitivity related to telmisartan therapy found in the current study? Recently published results of the ON- 
TARGET study could undermine the results of the present study. In the ONTARGET study no predomination of telmisartan over ramipril was found as far as the number of new cases of diabetes is concerned [45]. A similar effect, suggesting the lack of telmisartan influence on insulin sensitivity, was obtained in the TRANSCEND study, which compared telmisartan with placebo [46]. Nevertheless, it must be noted that in the ONTARGET and TRANSCEND studies, insulin resistance was not the inclusion criterion. In the present study, 22 out of 25 participants were insulin-resistant according to the definition of insulin resistance regarded for European population. Thus the demonstration of improvement of insulin sensitivity was probably easier in these insulin-resistant patients. Therefore, a clinical study including patients especially predisposed to diabetes may be required to prove clinical relevance of beneficial effect of telmisartan on carbohydrate metabolism. Moreover, one can speculate that the observation time in the ONTARGET and TRANSCEND studies was too short to find a significant difference in such a hard metabolic endpoint as the new onset of diabetes mellitus.

Insulin sensitivity improvement observed in the current study was independent of body weight and fat mass changes. Moreover, we did not observe changes in fat distribution by the DEXA method. However, we applied the DEXA method which allows to estimate the fat localized in specified body regions but cannot differentiate between visceral and subcutaneous fat. In two other studies a significant reduction in visceral fat measured by computed tomography was observed after a 6-month telmisartan treatment in patients with arterial hypertension [47] or metabolic syndrome [48]. Such changes observed in these studies may interfere with the estimation of insulin sensitivity changes.

HMW is the main metabolically active fraction of adiponectin - an adipokine which is supposed to have antidiabetic properties. A HMW fraction appears as a result of posttranslational modifications inside the adipocytes. The serum concentration of the HMW fraction is decreased in patients with diabetes mellitus and coronary artery disease. In the current study we found the increase in total adiponectin and its HWM fraction plasma concentration after a 6-month telmisartan therapy. Therefore, we confirmed the beneficial influence of telmisartan on total adiponectin serum concentration found in other studies [40, 49-51]. Until now the influence of telmisartan on the HWM fraction of adiponectin has been studied only in a single recently published study [52]. Similarly, as in the current study an increase of plas- ma concentration of the HWM adiponectin fraction after telmisartan therapy was found. Therefore, it seems that telmisartan increases the production of HMW multimers inside the adipocytes. The results obtained suggest that the increase in adiponectin and its HMW fraction concentration may contribute to the improvement in insulin sensitivity. The excretion of adiponectin and its HMW fraction may be induced via receptor PPAR $\gamma$ activation.

These results of clinical studies are in line with the recently published adipocyte culture study. Brody et al. [53] found that telmisartan and, to a lesser extent, losartan, has increased production and secretion of adiponectin from 3T3-L1 adipocytes.

Obesity is accompanied by an increased concentration of inflammatory markers ('microinflammation'), which contributes to metabolic disturbances and accelerates development of atherosclerosis. We have observed a significant reduction of serum concentrations of hsCRP and IL8. The levels of TNF $\alpha$ and IL- 6 only tended to decline. The completely original aspect of the study was the estimation of IL-8 plasma concentration that seems to have an important role in the pathogenesis of atherosclerosis. The present study is the first to measure the influence of one of the angiotensin II receptor type 1 antagonists on plasma IL-8 concentration. Adipose tissue is the main source of IL-8 in obesity [30]. Perhaps the increase in total adiponectin and its HMW fraction concentration observed in our study could also be the result of the reduction of microinflammation.

\section{Conclusion}

Telmisartan monotherapy improves insulin sensitivity by increasing the plasma adiponectin concentration, including its HMW fraction, and by suppressing microinflammation. Both the improvement of insulin sensitivity and suppression of inflammation are of potential clinical significance.

\section{Acknowledgement}

The study was carried out as a research project supported by a grant from the State Committee of Scientific Research in Poland (N402 078834).

\section{Disclosure Statement}

The authors have no conflicts of interest to disclose. 


\section{References}

1 Obesity and Overweight. Factsheet No. 311. http://www.who.int/mediacentre/factsheets/ fs311/en/index.html (accessed March 2011).

2 Diabetes. Factsheet No. 312. http://www. who.int/mediacentre/factsheets/fs311/en/ index.html (accessed January 2011).

-3 Padwal R, Laupacis A: Antihypertensive therapy and incidence of type 2 diabetes: a systematic review. Diabetes Care 2004;27: 247-255.

4 Lindholm LH, Ibsen H, Dahlöf B, Devereux RB, Beevers G, de Faire U, Fyhrquist F, Julius S, Kjeldsen SE, Kristiansson K, LederballePedersen O, Nieminen MS, Omvik P, Oparil S, Wedel H, Aurup P, Edelman J, Snapinn S; LIFE Study Group: Cardiovascular morbidity and mortality in patients with diabetes in the Losartan Intervention For Endpoint reduction in hypertension study (LIFE): a randomised trial against atenolol. Lancet 2002; 359:1004-1010.

5 Julius S, Kjeldsen SE, Weber M, Brunner HR, Ekman S, Hansson L, Hua T, Laragh J, McInnes GT, Mitchell L, Plat F, Schork A, Smith B, Zanchetti A; VALUE trial Group: Outcomes in hypertensive patients at high cardiovascular risk treated with regimens based on valsartan or amlodipine: the VALUE randomised trial. Lancet 2004;363:2022-2031.

6 Lithell H, Hansson L, Skoog I, Elmfeldt D, Hofman A, Olofsson B, Trenkwalder P, Zanchetti A; SCOPE Study Group: The Study on Cognition and Prognosis in the Elderly (SCOPE): principal results of a randomized double-blind intervention trial. J Hypertens 2003;21:875-886.

$>7$ Benson SC, Pershadsingh HA, Ho CI, Chittiboyina A, Desai P, Pravenec M, Qi N, Wang J, Avery MA, Kurtz TW: Identification of telmisartan as a unique angiotensin II receptor antagonist with selective PPAR $\gamma$-modulating activity. Hypertension 2004;43:9931002 .

$>8$ Kersten S, Desvergne B, Wahli W: Roles of PPARs in health and disease. Nature 2000; 405:421-424

$\checkmark 9$ Arita Y, Kihara S, Ouchi N, Takahashi M, Maeda K, Miyagawa J, Hotta K, Shimomura I, Nakamura T, Miyaoka K, Kuriyama H, Nishida M, Yamashita S, Okubo K, Matsubara K, Muraguchi M, Ohmoto Y, Funahashi T, Matsuzawa Y: Paradoxical decrease of an adipose-specific protein, adiponectin, in obesity. Biochem Biophys Res Commun 1999;257:79-83.

-10 Hotta K, Funahashi T, Arita Y, Takahashi M, Matsuda M, Okamoto Y, Iwahashi H, Kuriyama $\mathrm{H}$, Ouchi N, Maeda K, Nishida M, Kihara S, Sakai N, Nakajima T, Hasegawa K, Muraguchi M, Ohmoto Y, Nakamura T, Yamashita S, Hanafusa T, Matsuzawa Y: Plasma concentration of a novel, adiposespecific protein, adiponectin, in type 2 diabetic patients. Arterioscler Thromb Vasc Biol 2000;20:1595-1599.
11 Adamczak M, Wiecek A, Funahashi T, Chudek J, Kokot F, Matsuzawa Y: Decreased plasma adiponectin concentration in patients with essential hypertension. Am J Hypertens 2003;16:72-75.

12 Dzielińska Z, Januszewicz A, Wiecek A, Demkow M, Makowiecka-Cieśla M, Prejbisz A, Kadziela J, Mielniczuk R, Florczak E, Janas J, Januszewicz M, Ruzyłło W: Decreased plasma concentration of a novel anti-inflammatory protein - adiponectin - in hypertensive men with coronary artery disease. Thromb Res 2003;110:365-369.

13 Kadowaki T, Yamauchi T: Adiponectin and adiponectin receptors. Endocr Rev 2005;26: 439-451.

14 Pajvani UB, Hawkins M, Combs TP, Rajala MW, Doebber T, Berger JP, Wagner JA, Wu M, Knopps A, Xiang AH, Utzschneider KM, Kahn SE, Olefsky JM, Buchanan TA, Scherer PE: Complex distribution, not absolute amount of adiponectin, correlates with thiazolidinedione-mediated improvement in insulin sensitivity. J Biol Chem 2004;279: 12152-12162.

15 Fisher FF, Trujillo ME, Hanif W, Barnett AH, McTernan PG, Scherer PE, Kumar S: Serum high molecular weight complex of adiponectin correlates better with glucose tolerance than total serum adiponectin in Indo-Asian males. Diabetologia 2005;48: 1084-1087.

16 Inoue T, Kotooka N, Morooka T, Komoda H, Uchida T, Aso Y, Inukai T, Okuno T, Node K: High molecular weight adiponectin as a predictor of long-term clinical outcome in patients with coronary artery disease. Am J Cardiol 2007;100:569-574.

17 Considine RV, Sinha MK, Heiman ML, Kriauciunas A, Stephens TW, Nyce MR, Ohannesian JP, Marco CC, McKee LJ, Bauer TL, Caro JF: Serum immunoreactive-leptin concentrations in normal-weight and obese humans. N Engl J Med 1996;334:292-295.

18 Papafragkaki DK, Tolis G: Obesity and renal disease: a possible role of leptin. Hormones (Athens) 2005;4:90-95.

19 Tonelli J, Li W, Kishore P, Pajvani UB, Kwon E, Weaver C, Scherer PE, Hawkins M: Mechanisms of early insulin-sensitizing effects of thiazolidinediones in type 2 diabetes. Diabetes 2004;53:1621-1629.

20 Guerre-Millo M: Adipose tissue hormones. J Endocrinol Invest 2002;25:855-861.

21 Guerre-Millo M: Adipose tissue and adipokines: for better or worse. Diabetes Metab 2004;30:13-19.

22 Sonnenberg GE, Krakower GR, Kissebah AH: A novel pathway to the manifestations of metabolic syndrome. Obes Res 2004;12: $180-186$.
23 Bastard JP, Jardel C, Bruckert E, Blondy P, Capeau J, Laville M, Vidal H, Hainque B: Elevated levels of interleukin- 6 are reduced in serum and subcutaneous adipose tissue of obese women after weight loss. J Clin Endocrinol Metab 2000;85:3338-3342.

24 Vozarova B, Weyer C, Hanson K, Tataranni PA, Bogardus C, Pratley RE: Circulating interleukin- 6 in relation to adiposity, insulin action, and insulin secretion. Obes Res 2001; 9:414-417.

25 Jazet IM, Pijl H, Meinders AE: Adipose tissue as an endocrine organ: impact on insulin resistance. Neth J Med 2003;61:194-212.

26 Coppack SW: Pro-inflammatory cytokines and adipose tissue. Proc Nutr Soc 2001;60: 349-356.

27 Pittas AG, Joseph NA, Greenberg AS: Adipocytokines and insulin resistance. J Clin Endocrinol Metab 2004;89:447-452.

28 Reape TJ, Groot PH: Chemokines and atherosclerosis. Atherosclerosis 1999;147:213225 .

29 Zozulińska D, Majchrzak A, Sobieska M, Wiktorowicz K, Wierusz-Wysocka B: Serum interleukin-8 level is increased in diabetic patients. Diabetologia 1999;42:117-118.

30 Strączkowski M, Dzienis-Strączkowska S, Stępień A, Kowalska I, Szelachowska M, Kinalska I: Plasma interleukin-8 concentrations are increased in obese subjects and related to fat mass and tumor necrosis factor- $\alpha$ system. J Clin Endocrinol Metab 2002;87: 4602-4606.

31 DeFronzo RA, Tobin JD, Andres R: Glucose clamp technique: a method for quantifying insulin secretion and resistance. Am J Physiol 1979;237:214-223.

32 Fogari R, Zoppi A, Ferrari I, Mugellini A, Preti P, Lazzari P, Derosa G: Comparative effects of telmisartan and eprosartan on insulin sensitivity in the treatment of overweight hypertensive patients. Horm Metab Res 2009;41:893-898.

33 Belfiore F, Iannello S, Volpicelli G: Insulin sensitivity indices calculated from basal and OGTT-induced insulin, glucose, and FFA levels. Mol Genet Metab 1998;63:134-141.

34 Katz A, Nambi SS, Mather K, et al: Quantitative insulin sensitivity check index: a simple, accurate method for assessing insulin sensitivity in humans. J Clin Endocrinol Metab 2000;85:2402-2410.

35 Radikova Z, Koska J, Huckova M, Ksinantova L, Imrich R, Vigas M, Trnovec T, Langer $\mathrm{P}$, Sebokova E, Klimes I: Insulin sensitivity indices: a proposal of cut-off points for simple identification of insulin-resistant subjects. Exp Clin Endocrinol Diabetes 2006; 114:249-256.

36 Akel A, Wiecek A, Nowicki M, Kokot F: The effect of treatment with enalapril versus losartan on levels of insulin resistance in patients with essential hypertension. Pol Arch Med Wewn 2000;103:123-131. 
37 Sharma AM, Davidson J, Koval S, Lacourcière Y: Telmisartan/hydrochlorothiazide versus valsartan/hydrochlorothiazide in obese hypertensive patients with type 2 diabetes: the SMOOTH study. Cardiovasc Diabetol 2007;6:28.

-38 Benndorf RA, Rudolph T, Appel D, Schwedhelm E, Maas R, Schulze F, Silberhorn E, Böger RH: Telmisartan improves insulin sensitivity in nondiabetic patients with essential hypertension. Metabolism 2006;55: 1159-1164.

>39 Nagel JM, Tietz AB, Göke B, Parhofer KG: The effect of telmisartan on glucose and lipid metabolism in nondiabetic, insulin-resistant subjects. Metabolism 2006;55:1149-1154.

40 Derosa G, Fogari E, D’Angelo A, Cicero AF, Salvadeo SA, Ragonesi PD, Ferrari I, Gravina A, Fassi R, Fogari R: Metabolic effects of telmisartan and irbesartan in type 2 diabetic patients with metabolic syndrome treated with rosiglitazone. J Clin Pharm Ther 2007; 32:261-268

-41 Usui I, Fujisaka S, Yamazaki K, Takano A, Murakami S, Yamazaki Y, Urakaze M, Hachiya H, Takata M, Senda S, Iwata M, Satoh A, Sasaoka T, Ak ND, Temaru R, Kobayashi M: Telmisartan reduced blood pressure and HOMA-IR with increasing plasma leptin level in hypertensive and type 2 diabetic patients. Diabetes Res Clin Pract 2007; 77:210-214.

-42 Vitale C, Mercuro G, Castiglioni C, Cornoldi A, Tulli A, Fini M, Volterrani M, Rosano GM: Metabolic effect of telmisartan and losartan in hypertensive patients with metabolic syndrome. Cardiovasc Diabetol 2005; 4:6-13.
43 Bahadir O, Uzunlulu M, Oguz A, Bahadir MA: Effects of telmisartan and losartan on insulin resistance in hypertensive patients with metabolic syndrome. Hypertens Res 2007;30:49-53.

44 Derosa G, Ragonesi PD, Mugellini A, Ciccarelli L, Fogari R: Effects of telmisartan compared with eprosartan on blood pressure control, glucose metabolism and lipid profile in hypertensive, type 2 diabetic patients: a randomized, double-blind, placebo-controlled 12-month study. Hypertens Res 2004; 27:457-464.

45 Yusuf S, Teo KK, Pogue J, Dyal L, Copland I, Schumacher H, Dagenais G, Sleight P, Anderson C; ONTARGET Investigators: Telmisartan, ramipril, or both in patients at high risk for vascular events. N Engl J Med 2008;358:1547-1559.

46 Yusuf S, Teo K, Anderson C, Pogue J, Dyal L, Copland I, Schumacher H, Dagenais G, Sleight P; Telmisartan Randomised AssessmeNt Study in ACE iNtolerant subjects with cardiovascular Disease (TRANSCEND) Investigators: Effects of the angiotensin-receptor blocker telmisartan on cardiovascular events in high-risk patients intolerant to angiotensin-converting enzyme inhibitors: a randomised controlled trial. Lancet 2008; 372:1174-1183.

47 Chujo D, Yagi K, Asano A, Muramoto H, Sakai S, Ohnishi A, Shintaku-Kubota M, Mabuchi H, Yamagishi M, Kobayashi J: Telmisartan treatment decreases visceral fat accumulation and improves serum levels of adiponectin and vascular inflammation markers in Japanese hypertensive patients. Hypertens Res 2007;30:1205-1210.
48 Shimabukuro M, Tanaka H, Shimabukuro T: Effects of telmisartan on fat distribution in individuals with the metabolic syndrome. J Hypertens 2007;25:841-848.

-49 Delles C, Raff U, Mimran A, Fauvel JP, Ruilope LM, Schmieder RE: Effects of telmisartan and ramipril on adiponectin and blood pressure in patients with type 2 diabetes. Am J Hypertens 2008;21:13301336.

50 Hong SJ, Shim WJ, Choi JI, Joo HJ, Shin SY, Park SM, Lim SY, Lim DS: Comparison of effects of telmisartan and valsartan on late lumen loss and inflammatory markers after sirolimus-eluting stent implantation in hypertensive patients. Am J Cardiol 2007;100: 1625-1629.

51 Makita S, Abiko A, Naganuma Y, Moriai Y, Nakamura M: Effects of telmisartan on adiponectin levels and body weight in hypertensive patients with glucose intolerance. Metabolism 2008;57:1473-1478.

52 Komiya N, Hirose H, Kawabe H, Itoh H, Saito I: Effects of telmisartan therapy on metabolic profiles and serum high-molecular-weight adiponectin level in Japanese male hypertensive subjects with abdominal obesity. J Ather Thromb 2009;16:137-142.

53 Brody R, Peleg E, Grossman E, Sharabi Y: Production and secretion of adiponectin from 3T3-L1 adipocytes: comparison of antihypertensive drugs. Am J Hypertens 2009; 22:1126-1129. 